\title{
Why International Organizations are Accountable to You
}

Eyal Benvenisti*

(Forthcoming in: Resolving Conflicts in the Law, Essays in Honour of Lea Brilmayer (Chiara Giorgetti and Natalie Klein, Eds., 2019)

\begin{abstract}
The aim of this essay is to identify a legal basis for accountability obligations of international organizations (IOs) toward individuals affected by their policies. More specifically, I ask why should, for example, the European Union or the World Trade Organization be accountable to individuals who are not citizens of states parties to those organizations, but nevertheless may be affected by their policies. I explore three traditional foundations for accountability obligations under domestic law as potential grounds for such accountability obligation: the rule of law, human rights, and trusteeship. After rejecting the first two candidates, the essay offers the trusteeship concept as one that can and should serve as the normative bedrock for the emergence of administrative law at the global level. I also argue that this concept is already ingrained in the law that is incumbent upon IOs.
\end{abstract}

"If this is true with regard to every species of political dominion, and every description of commercial privilege, none of which can be original self-derived rights, ... then such rights, or privileges, ..., are all in the strictest sense a trust; and it is of the very essence of every trust to be rendered accountable."

Edmund Burke, $1783^{1}$

\section{Introduction}

I was still a student of Lea Brilmayer's when I read her Justifying International Acts (1989). In this pathbreaking book, Brilmayer reminded us that international law until that moment (with glasnost and perestroika, the Cold War about to be won) has been focusing on justifying the "horizontal" (inter-state) obligations. Not enough attention has been paid to the "diagonal" relationship, namely the relations

\footnotetext{
* Whewell Professor of International Law, University of Cambridge, C C Ng Fellow of Jesus College, Cambridge, Professor, Tel Aviv University Faculty of Law, Global Professor of Law, New York University. For many helpful comments I wish to thank Doreen Lustig, Tamar Megiddo, and the participants in workshops held at Yale Law School and Tel Aviv University Faculty of Law. Research for this essay was supported by the ERC Advanced Grant (grant No. 323323).

14 Edmund Burke, Selected Works of Edmund Burke 64 (E. J. Payne ed., 1999), http://lfoll.s3.amazonaws.com/titles/659/Burke_0005-04_EBk_v6.0.pdf (last visited Aug. 11, 2018) (Emphasis in original) (Edmund Burke's Speech, Dec. 1, 1783 on the East India Bill).
} 
between states and citizens of other states. Well ahead of her contemporaries, Brilmayer forcefully argued for the need to develop and apply a theoretical perspective that would justify the exercise of power by one state over foreign individuals. One could not think of a more timely theoretical challenge to international law and politics in a world that was about to be dominated by a single power. Lea's argument continued to challenge my own thinking and it was more than twenty years later that I attempted to offer my theoretical lens for such diagonal relationships. ${ }^{2}$ This chapter applies this lens to international organizations (IOs), as the basis of their obligation to justify their exercise of power over individuals who are affected by their acts and omissions.

The law on IOs that emerged after the Second World War was imbued with irrefutable confidence in their inherent impartiality and competence and hence reflected an assumption that the subjection of IOs to legal discipline and judicial review would be unnecessary and even counterproductive. ${ }^{3}$ The law that evolved by a West-dominated International Court of Justice (ICJ) ${ }^{4}$ (and against Soviet opposition on and outside the ICJ bench), ${ }^{5}$ exudes faith in international decision-makers as skilful public servants who selflessly toil for the common good. ${ }^{6}$ The law insulates these actors from internal and external scrutiny and absolves them of any inherent legal obligations. Despite many examples to the contrary, the international law on IOs continues to do so to this day.

Mistrust in IOs began to trickle through into academic and legal discourse only well after the end of the Cold War and following protests by civil society activists. Gradually, the proliferation of IOs and the

\footnotetext{
${ }^{2}$ Eyal Benvenisti, Sovereigns as Trustees of Humanity: On the Accountability of States to Foreign Stakeholders, 107 AM. J. INT'L L. 295 (2013).

${ }^{3}$ Jan Klabbers, The Life and Times of the Law of International Organizations, 70 NORDIC J. INT'L L. 287, 288 (2001).

${ }^{4}$ Hans J. Morgenthau, The New United Nations and the Revision of the Charter, 16 REV. PoL. 3, 4, 6-8, 15 (1954) ("While in its relations with its members it is an international government, in its relations with the Soviet bloc the new United Nations is a grand alliance opposing another grand alliance."). On the UN as a Western actor, see MARK

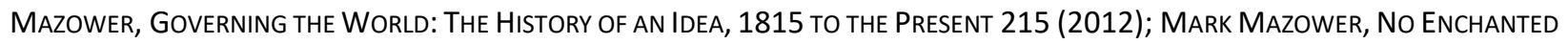
Palace: The End of Empire And the Ideological Origins of the United Nations 77 (2008); PAul KenNedy, The Parlament of MAN: THe PAST, PRESENT, AND FUtURE OF THE United NATIONS 155 (2006).

${ }^{5}$ Kazimierz Grzybowski, Socialist Judges in the International Court of Justice, 1964 DUKE L.J. 536 (Socialist judges do not see the UN as having introduced basic changes in the legal position of the member states, and the latter therefore may continue to question the legality of its resolutions). For such views see Judge Milovan Zoricic, of Yugoslavia, in Conditions of Admission of a State to the United Nations, Advisory Opinion, 1948 I.CJ. Rep. 57, 106 (May 28); Judge Winiarski, of Poland, in Certain Expenses of the United Nations (Article 17, Paragraph 2, of the Charter), Advisory Opinion, 1962 I.C.J Rep. 151, 181 (July 20); Judge Winiarski, in Effects of Awards of Compensation Made by the United Nations administrative Tribunal, Advisory Opinion, 1954 I.C.J Rep. 47, 63 (July 13); Judge Koretsky, of the Soviet Union, in Certain Expenses, at 181. On the Soviet attitude toward the law on IOs, see GuY FITI SINCLAIR, TO REFORM THE WORLD: INTERNATIONAL ORGANIZATIONS AND THE MAKING OF MODERN STATES 140 (2017): International lawyers in the Soviet bloc argued vehemently that member states' sovereignty required their explicit consent to any expansion of UN powers. The idea of "constitutional growth" or "de facto amendment" of the Charter was anathema, not least because it served to legitimize what they saw as the unlawful manipulation of Charter rules and procedures by the United States and its allies.

See also GRIGORY TUNKIN, INTERNATIONAL LAW IN THE INTERNATIONAL SYSTEM 169, 173-78 (1975).

${ }^{6}$ On demands for accountability of the League of Nations through 'publicity' (but also the 'reinvention and rehabilitation of secrecy') in the inter-war period, see Megan Donaldson, The Survival of the Secret Treaty: Publicity, Secrecy, and Legality in the International Order, 111 AM. J. INT'L L. 575 (2017).
} 
growing dependency on them brought home also the understanding that powerful state executives and special interests were, in fact, steering IOs in favour of their own ends and deviating from the common good. ${ }^{7}$ Responding to this realization, the academic literature since the early 2000 s pressed for more accountable IOs. They did so by borrowing from domestic concepts of the rule of law and sound practices of decision-making by public bodies, implicitly or explicitly regarding IOs as exercising public authority. ${ }^{8}$

But while the operators of certain IOs have adopted and even embraced a 'culture of accountability, ${ }^{\prime 9} \mathrm{a}$ major impediment continues to undercut the demand for accountability: the law on IOs fails to provide a positive legal basis for grounding the rigorous requirements of public decision-making as understood in well-functioning democracies. In fact, this law stands in sharp contrast to domestic public law doctrines such as ultra vires or détournement de pouvoir that have inspired the evolution of sound administrative law duties in Western democracies. This law insulates IOs (and their employees) from any external legal discipline or demand for accountability for their acts: IOs have legal personality that is independent of the member states; their powers are broadly defined - even implied - by their constitutive treaty; they are "bound [only] by any obligations incumbent upon them under general rules of international law, under their constitutions or under international agreements to which they are parties," (my emphasis); ${ }^{10}$ and they enjoy immunity from domestic court review. ${ }^{11}$ These are not exactly the building blocks from which one can construct a firm grounding for rigorous rule of law obligations.

This essay seeks to offer such grounding for 10 accountability. The admittedly narrow doctrinal opening is provided by the above-mentioned recognition that IOs are bound by "obligations incumbent upon them under general rules of international law." ${ }^{12}$ What obligation could generate 10 accountability toward people affected by their (or their employee's) acts? To respond to this question, the essay examines the three possible grounds that have informed the evolution of the principle of accountability under major domestic administrative law systems. The first ground is the principle of the rule of law, which stipulates that the executive has only that power granted to it by the legislature and that the exercise of that power is subject to specific demands. The second ground is based on the human rights of those affected by public

\footnotetext{
${ }^{7}$ Eyal Benvenisti, Exit and Voice in the Age of Globalization, 98 MICH. L. REV. 167 (1999) (arguing that informationbased capture at the global level is even more intense than at the domestic level). On selective access to information as empowering special interests see Anthony Downs, An Economic Theory of Political Action in a Democracy, $65 \mathrm{~J}$. POL. ECON. 135 (1957); Susanne Lohmann, An Information Rationale for the Power of Special Interests, 92 AM. POL. SCI. Rev. 809 (1998); Gene M. Grossman \& Elhanan Helpman, SpeCial Interest Politics (2001).

${ }^{8}$ Benedict Kingsbury, Nico Krisch \& Richard Stewart, The Emergence of Global Administrative Law, 68 LAW \& CONTEMP. Probs. 15 (2005); Global Administrative law: The Casebook (Sabino Cassese et al eds., 3d ed. 2012); Armin von Bogdandy \& INGo Venzke, In Whose Name? A Public LaW Theory of InTernational Adjudication (2014); International Public Authority, MAX PLANCK INSTITUTE, http://www.mpil.de/de/pub/forschung/nachrechtsgebieten/voelkerrecht/ipa.cfm (last visited Aug. 11, 2018).

${ }^{9}$ Michael Zürn \& Matthew Stephen, The View of Old and New Powers on the Legitimacy of International Institutions, 30 POL. 91, 98-99 (2010).

${ }^{10}$ Interpretation of the Agreement of 25 March 1951 between the WHO and Egypt, Advisory Opinion, 1980 I.C.J. Rep. 73, 937 (Dec. 20). On this statement see JAN KLABBERS, AN INTRODUCTION TO INTERNATIONAL LAW 38-39, 46-47 (2d ed. 2009); Eyal Benvenisti, EJIL Foreword: Upholding Democracy Amid the Challenges of New Technology: What Role for the Law of Global Governance?, 29 EUR. J. INT'L L. 9, 22-23 (2018).

${ }^{11}$ On the limitations of this law for establishing 10 accountability see Benvenisti, supra note 10 , at 16-30.

${ }^{12}$ See Interpretation of the Agreement, supra note 10., id.
} 
actors, and the corresponding duty of the public body to respect and protect those rights. The third claim grounds accountability obligations in the idea of a trust between the administrative agency and the trustor, be it the king, the legislator or the citizens, who is therefore entitled to be given account for what is done in its name. ${ }^{13}$ After rejecting the first two grounds (Part II) the essay elaborates on the third ground, promoting the thesis that IOs, just like states, should be regarded as trustees of humanity and as such they are accountable to those whom they affect by their policies, even if they are foreign nationals.

\section{Two False Starts: the Rule of Law and Human Rights}

\section{(a) The Rule of Law}

When Alfred Venn Dicey contrasted the English administrative law system to the French droit administratif, he focused on the principle of the rule of law. This principle stipulated that all - private persons and public officials - are equally subjected to the law. ${ }^{14}$ Therefore, when English public officials operated beyond their legal mandate - when they acted ultra vires - they lost their official mantle and were transformed into a private person who lacked authority or public status:

Any official who exceeds the authority given him by the law incurs the common law responsibility for his wrongful act; he is amenable to the authority of the ordinary Courts, and the ordinary Courts have themselves jurisdiction to determine what is the extent of his legal power, and whether the orders under which he has acted were legal and valid. ${ }^{15}$

The agent who oversteps her legal mandate becomes, by that very act, a private individual, just like Cinderella at the stroke of midnight. Her orders are necessarily and promptly null and void. This doctrine has provided an effective judicial check on executive power, because the agent was required to demonstrate the legal source for her exercise of authority. This concept of the rule of law is quite narrow

\footnotetext{
${ }^{13}$ Several political philosophers are satisfied with a grounding that is based simply on human interaction, namely positing that individuals owe account to others for the effects of their behavior on society. See, e.g., AMARTYA SEN, THE IDEA OF JUSTICE 46 (2009):

The basic general obligation here must be to consider seriously what one can reasonably do to help the realization of another person's freedom, taking note of its importance and influenceability, and of one's own circumstances and likely effectiveness. There are, of course, ambiguities here and scope for disagreement, but it does make a substantial difference in determining what one should do to acknowledge an obligation to consider this argument seriously.

See also Ronald Dworkin, A New Philosophy for International Law, 41 PHIL. \& PUB. Aff. 1 (2013) (states, just like individuals, need to further improve the system they constitute part of). This idea goes back to Vattel (see discussion in Benvenisti, supra note 2, at 302, 307-10. But to ground public law obligations, which go beyond what individuals owe each other when interacting in the private sphere, we need a stronger theory that singles out "public action."

${ }^{14}$ Dicey's concept of the rule of law consisted of three principles: "that with us no man is above the law, that here every man, whatever be his rank or condition, is subject to the ordinary law of the realm and amenable to the jurisdiction of the ordinary tribunals [and] that the general principles of the constitution are [...] with us the result of judicial decisions determining the rights of private persons in particular cases brought before the Courts." A. V. DiCEY, LeCtuRES INTROductory to THE StUdy OF THE LAW OF THE CONSTITUtion 171-178 (London, MacMillan \& Co., 1885). ${ }^{15} / d$., at 384-85.
} 
in its source. Synonyms that capture the same approach are "the principle of legality" or the concept of "the rule by law." ${ }^{16}$ But with judicial creativity and determination, this rule of law-grounded doctrine was extended beyond the formal authority to act to cover also the manner of action (the procedural aspects, including the right of hearing and due process more generally) and the motivation for action (substantive limitations on the exercise of discretion). The court's authority to review administrative action also derived from the need to ensure the rule of law. ${ }^{17}$ As Lord Woolf explained, "[t]here are other principles which are part of the rule of law, for example, that the public are entitled to have resort to the courts; that the courts are for the resolution of their disputes; that it is the courts' responsibility to protect the public against the unlawful activities of others including the executive; and that it is the responsibility of the courts to determine the proper interpretation of the law." ${ }^{18}$

The rule of law approach informed the evolution of domestic administrative law in other legal systems as well. Carol Harlow notes that "[e]very Western administrative law system is founded on the rule of law ... The rule of law ideal forms the central background theory against which the principles of administrative law operate, while at the same time acting as a governing principle." ${ }^{19}$ In fact, Neville Brown and John Bell argue that the French principle of légalité - "the idea that the administration must be compelled to observe the law [...] is something much more that the English and Scottish doctrines of ultra vires" in its procedural and substantive demands from the administration. ${ }^{20}$ Augmented by the judicial recourse to the principes généraux du droit, the entire edifice of French administrative law is built on this concept. ${ }^{21}$

Like a stalactite that form in limestone caverns from the slow accumulation of lime from mineral-laden drops of water, administrative law was born from this rule of law concept. Arguably, the strength of Dicey's rule of law approach was in the mandate it gave the courts to deliberate on the meaning of the authorization that the law had granted the public official, thereby incrementally expanding the law's demands from the administrative body.

Unfortunately, that first drop of limestone-laden water, that necessary narrow beginning, is missing in the international legal space. The reason for this is the normative absence in the international legal space of the motivation for the domestic rule of law concept: the agency relationship between the principal who - the king, the voter - and the agent, the public official who is tasked by the former to serve its interests. Dicey emphasized these relationships as the key for the rule of law demand when he spoke about "[a]ny official who exceeds the authority given him by the law." But in international law, IOs do not derive their authority to act from states or from international law, and there is no theory that will transform the 10 that oversteps its authority into a powerless Cinderella. In fact, the law endorses the opposite approach as the doctrine of implied powers allows IOs to expand their remit beyond the explicit authorizing text.

\footnotetext{
16 Jeremy Waldron, The Rule of Law in Public Law (New York University Pub. Law \& Legal Theory Working Papers, Paper No. 481, 2014). See also Brian TAMANAHA, ON THE Rule Of LaW: History, Politics, TheORY 3 (2004).

${ }^{17}$ See Carol Harlow, Global Administrative Law: The Quest for Principles and Values, 17 EUR. J. INT'L L. 187, 195 (2006); Harry Woolf, Judicial Review - The Tensions between the Executive and the Judiciary, 114 LAW Q. REV. 579 (1998).

18 Woolf, supra note 17 , at 581.

19 Harlow, supra note 17 , at 190.

${ }^{20}$ NeVille L. Brown \& John S. Bell, French Administrative LaW 202 (4th ed. 1993).

${ }^{21}$ Id. at 205-23; JeAN RIVERo \& JeAN WALINE, DROIT AdMINISTRATIF [ADMINISTRATIVE LAW] 260-64 (20th ed. 2004).
} 
The law reflects the view that like states, IOs remain private actors ${ }^{22}$ with the legal capacity to do whatever they wish to unless limited by the law. Except the jus cogens norms, that are too remote from questions of accountability, ${ }^{23}$ the prevailing law on IOs does not support any theory that can accommodate external, public law obligations on IOs. Hence, the rule of law approach is hardly reconcilable with "obligations incumbent [on IOs] under general rules of international law."24

\section{(b) Human Rights}

Could international human rights law serve as an alternative candidate for accountability obligations of IOs? This is in principle the German approach to administrative law that stipulates that the freedom of action of administrative agencies is restricted by the individual's constitutional or statutory rights. ${ }^{25}$ This approach highlights two types of procedural obligations that derive from human rights to restrict governmental action: first, independent rights such as the right to information, the right to access to judicial remedies, and the right to due process; and second, derivative procedural rights that serve to indirectly protect substantive rights such as the right to life, self-determination, and property, that is, secondary rights that demand compliance with due process obligations in the course of limiting those rights. $^{26}$

The human rights approach to accountability is conceptually weaker from the one based on the rule of law. The human rights perspective is limited to the citizen's human or constitutional rights. It thus does not question the very authority to act, but instead assumes an authority to act and assesses only the effects of the act on the relevant rights. An entire sphere of governmental activity, that which does not affect individual rights, is thus protected from external legal scrutiny. The decision-maker will remain a princess even if she violated the rights of others; the Cinderella-like effects of overstepping authority bounds do not exist under this vision. Conceptually, the scope of review is much limited, since as long as her rights are not violated, the citizen has no standing to demand accountability or involvement in the decision-making process. For those affected by the administrative agency, a preliminary question of

\footnotetext{
22 See Hersch Lauterpacht, Private law Sources and Analogies of International Law (1927).

${ }^{23}$ The European Court of First Instance in the Kadi and Yusuf and Al Barakaat judgments rejected the claim that procedural guarantees against the freezing of assets by the UN Security Council including the right to be heard constituted violation of jus cogens norms (judgments of the Court of First Instance of the European Communities of Sept. 21, 2005 in Case T-315/01 Kadi v. Council and Comm'n, 2005 E.C.R. II-3649, and Case T-306/01 Yusuf and Al Barakaat International Foundation v. Council and Comm'n, 2005 E.C.R. II-3533).

${ }^{24}$ See Interpretation of the Agreement, supra note 10., id.

${ }^{25}$ See GRUNDGESETZ [GG] [Basic Law], art. 19(4) ("Should any person's rights be violated by public authority, he may have recourse to the courts."); VERWALTUNGSGERICHTSORDNUNG [VwGO] [Code of Administrative Court Procedure], $\S$ 42, para. 2 (Unless otherwise provided by law, the action shall only be admissible if the plaintiff claims that his/her rights have been violated by the administrative act or its refusal or omission). See also Florian Becker, The Development of German Administrative Law, 24 GEo. MASON L. REV. 453, 466-67 (2017).

${ }^{26}$ See e.g. Article 6(1) of the European Convention on Human Rights (ECHR), "[i]n the determination of his civil rights and obligations .... everyone is entitled to a fair and public hearing within a reasonable time by an independent and impartial tribunal established by law." (Convention for the Protection of Human Rights and Fundamental Freedoms art. 6(1), Nov. 4, 1950, 213 U.N.T.S. 221). See also Eyal BenVenistI, The LAW of GLobal GovernanCE, 121-29 (2014).
} 
entitlement to rights becomes a precondition for the demand for accountability. Those affected by foreign governmental actors would be hard pressed to demonstrate such an entitlement.

This leads to the major impediment for borrowing 10 accountability from international human rights law. As is well known, while the Universal Declaration of Human Rights defines the rights as belonging to "all human beings" or "everyone," it conspicuously evades the assignment of the respective obligations and remains silent on the identity of the duty bearers. And when the duties are finally assigned, in the various human rights conventions, the duties to respect, protect, and provide rights are assigned to the state parties each with respect to individuals "subject to [their] jurisdiction." ${ }^{27}$ There is no collective, global obligation toward all individuals.

Hence, when attempting to import international human rights obligations to IOs, two questions emerge, both related to that concept of "jurisdiction." First, can global bodies ever be regarded as having "jurisdiction" over the relevant individuals (those affected by their policies)? And second, if so, what is the spatial scope of those human rights obligations that IOs are accountable for.

When IOs exercise direct control over individuals the answer is clear. This direct control explains for example why the Human Rights Committee found that the UN Mission in Kosovo (UNMIK) was responsible for the human rights situation in Kosovo as long as it administered that territory, despite the fact that UNMIK was not party to the 1966 Covenant on Civil and Political Rights. ${ }^{28}$ Similarly, it is obvious that the UN Security Council is responsible to individuals directly subject to its targeted sanctions regime in the counter-terrorism context. The same could easily apply also to employees of IOs who are entitled to expect their employer to respect and ensure their labor rights. ${ }^{29}$ But this still leaves out many more types of stakeholders who are indirectly affected by IOs: in what sense are these individuals "subject" to their "jurisdiction"? Does, for example, the World Bank "subject" individuals to its "jurisdiction" when it decides to offer loans to a local government, which then uses the loans to evict those individuals from their homes? ${ }^{30}$ And what about private bodies such as the International Olympic Committee which requires athletes to waive their privacy and other rights as a condition for participation in competitions?

\footnotetext{
${ }^{27}$ See, e.g., ECHR, supra note 22 art. 1, International Covenant on Civil and Political Rights, GA res. 2200A (XXI), art. 3, U.N. Doc. A/RES/21/2200 (Dec. 19, 1966) Art. 2. See also BenVenISTI, Global GovernANCE, supra note 26, at 132219.

${ }^{28}$ Concluding Observations of the Human Rights Committee Kosovo (Republic of Serbia), Hum. Rights Comm., 87th Sess., July 10-28, 2006, I 4, U.N. Doc. CCPR/C/UNK/CO/1 (Aug. 14, 2006), http://docstore.ohchr.org/SelfServices/FilesHandler.ashx?enc=6QkG1d\%2fPPRiCAqhKb7yhsq1Qo8bBNdeZ5f8Tz\%2b Mmes\%2f\%2bhnnX8dMdT1ka76gby7Q\%2f4D8nzFxqYYyrPwS9\%2fLHQzmhdlwFnBgqDGfqdviSRB3loqxQT4I6p9IBbR MmxnQYE (last visited Aug. 11, 2018). This position is based on its general comment No. 26 (1977) on the continuity of obligations. Robert McCorquodale, International Organisations and International Human Rights Law: One Giant Leap for Humankind, in International LaW AND Power: Perspectives on Legal ORder AND Justice 141, 160 (Kaiyan Homi Kaikobad \& Michael Bohlander eds., 2009) (concluding that IOs "can have human rights obligations, at least when exercising sovereign powers" like in Kosovo).

${ }^{29}$ Waite and Kennedy v. Germany, App. No. 26083/94, 1999-I Eur. Ct. H.R.

${ }^{30}$ See, e.g., Mariarita Circi, The World Bank Inspection Panel : The Indian Mumbai Urban Transport Project Case, in Global Administrative LAW: The CASEBOOK, supra note 8, at 100.
} 
Whereas the first question focused on the meaning of "subjection" to the jurisdiction, the second challenge addresses the spatial scope of the IOs" "jurisdiction." Again, it is clear that formal organizations that exercise direct territorial control over territory and people. For example, UN bodies administering territories, or UNHCR-run refugee centers, will be responsible in the area where they exercise effective control. ${ }^{31}$ But these are the exception, and in most cases it remains a question how to translate the concept of "jurisdiction" to the myriad of decision-making bodies that directly and indirectly affect diverse stakeholders across the globe, many of whom are citizens of states whose governments are not parties to the organization. Are, for example, those outside the EU "within the jurisdiction" of the EU when the EU adopts policies that directly or indirectly affect them ? $^{32}$

We therefore need a theory that will delimit the substantive and spatial scope of the human rights-based obligations that IOs owe to affected individuals who are not "subject" to their "jurisdiction" in the traditional, state-based sense that is reflected in contemporary international law. Contemporary human rights law does not provide such a theory.

\section{The Concept of Trusteeship of Humanity as a Potential Source for Accountability Obligations}

\section{(a) Trusteeship as the foundation of accountability obligations}

This section explores yet a third ground for 10 accountability that is free from the limitations of the first two approaches. This third ground is the concept of trusteeship. The concept of trusteeship is no stranger to domestic administrative law. ${ }^{33}$ It provided the basis for John Austin's definition of administrative law, long before Dicey's approach gained prominence:

Administrative law determines the ends and modes to and in which the sovereign powers shall be exercised: shall be exercised directly by the monarch or sovereign number, or shall be

\footnotetext{
31 See Devika Hovell, On Trust: The UN as Fiduciary (A Reply to Rosa Freedman) (LSE Law, Soc'y \& Eco. Working Papers, Paper No. 13, 2018); Gulielmo VerdiRAME, THE UN AND HuMAN RIGHTS: Who guARdS THE GUARDIANS? (2011); RALPH WILDE, INTERNATIONAL TERRITORIAL AdMINISTRATION (2006). See also EyAl BENVENISTI, THE INTERNATIONAL LAW OF OCCUPATION, 249-75 (2d ed. 2012).

32 Such foreign stakeholders may seek to rely on recent efforts to interpret the territorial scope of application of human rights conventions as extending beyond the state's "jurisdiction," and extend those arguments further to IOs. But this effort is also undermined by the lack of an accepted theory that could justify the spatial extension of international human rights obligations beyond the jurisdiction of the state parties to the IO. See MARKO MILANOVIC, Extraterritorial Application of Human Rights Treaties: LaW, Principles, ANd Policy 106-17 (2011); MAAStRICHT PRINCIPLES on Extraterritorial Obligations of States IN the AREA OF ECONOMIC, SOCIAL AND CULTURAL RightS (2011), https://www.etoconsortium.org/nc/en/main-navigation/library/maastricht-

principles/?tx_drblob_pi1\%5BdownloadUid\%5D=23 (last visited Aug 11, 2018); MARGOT E. SALOMON, GLOBAL RESPONSIBILITY FOR HUMAN RIGHTS: WORLD POVERTY AND THE DEVELOPMENT OF INTERNATIONAL LAW (2007). Wouter Vandenhole, Extraterritorial Human Rights Obligations: Taking Stock, Looking Forward, 2013 EUR. J. HUM. RTS. 804; Yuval Shany, Taking Universality Seriously: A Functional Approach to Extraterritoriality in International Human Rights Law, 7 L. \& ETHICs HuM. RTS. 47 (2013). But see Samantha Besson, The Extraterritoriality of the European Convention on Human Rights: Why Human Rights Depend on Jurisdiction and What Jurisdiction Amounts to, 25 LEIDEN J. INT'L L. 857 (2012).

${ }^{33}$ Frank H. Easterbrook \& Daniel R. Fischel, Contract and Fiduciary Duty, 36 J.L. \& EcoN. 425, 425 (1993).
} 
exercised directly by the subordinate political superiors to whom portions of those powers are delegated or committed in trust. ${ }^{34}$ (my emphasis).

Austin's view reflected a long-established practice of common-law judges, who, since the early seventeenth century, invoked and refined the concept of trust to limit the authority of office holders. ${ }^{35}$ This traditional concept also informed the democratic vision of state authority, derived from the people and therefore acting as the people's trustee, as exemplified in the writings of John Locke ${ }^{36}$ and James Madison. ${ }^{37}$ In the same vein, the Virginia Declaration of Rights (1776) asserted that "all power is vested in, and consequently derived from, the people; that magistrates are their trustees and servants and at all times amenable to them. ${ }^{\prime \prime 8}$ Even monarchic France recognized at the time the concept of trusteeship as limiting the authority of the king. ${ }^{39}$

The trusteeship vision continued to inform the evolution of domestic administrative law in several countries. Conceptualizing the government as a trustee offered courts grounds for extending the scope of administrative law to encompass also activities that are not expressly regulated by statute, such as the management of state owned property. As the Israeli Supreme Court declared in 1962, municipalities must manage property registered under their name as trustees of the public, the true if not formal owner of the property. ${ }^{40}$ Appropriately, the concept of trusteeship as the grundnorm of administrative law has recently garnered renewed attention from domestic administrative and constitutional law scholars. ${ }^{41}$

34 John Austin, Lectures on JuRisprudence OR The Philosophy of Positive LaW 465 (Robert Campbell ed., 5th ed. London, J. Murray 1885).

${ }^{35}$ Robert E. Mabry Rogers \& Stephen B. Young, Public Office as a Public Trust: A Suggestion that Impeachment for High Crimes and Misdemeanors Implies a Fiduciary Standard, 63 GEO. L.J. 1025, 1028-30 (1974) (citing English cases from as early as 1592 which 'embraced the private law concept of trust and extended its application even further in regulating public offices'). Note that Dicey also emphasized delegation, but from the law: embedded in the logic of delegation ('authority given him by the law').

${ }^{36}$ John Locke, Two Treatises OF Government 196-97 (Thomas I. Cook ed., Hafner Publishing Co. 1947) (1690):

Though in a constituted commonwealth, standing upon its own basis and acting according to its own nature, that is, acting for the preservation of the community, there can be but one supreme power which is the legislative, to which all the rest are and must be subordinate, yet, the legislative being only a fiduciary power to act for certain ends, there remains still in the people a supreme power to remove or alter the legislative when they find the legislative act contrary to the trust reposed in them; for all power given with trust for the attaining an end being limited by that end, whenever that end is manifestly neglected or opposed, the trust must necessarily be.

See also id. at 204 on discretion.

37 James Madison, The Federalist, 46, in The Federalist 315, 315 (Jacob E. Cooke ed., Wesleyan Univ. Press 2008)

(1788) ("The Federal and State Governments are in fact but different agents and trustees of the people, instituted with different powers, and designated for different purposes."); Alexander Hamilton, The Federalist, 65, in id. at 439, 440 ("The delicacy and magnitude of a trust which so deeply concerns the political reputation and existence of every man engaged in the administration of public affairs speak for themselves.").

${ }^{38}$ George Mason \& Thomas LUdWell LeE, The VIRGINIA DeCLARAtion of Rights § 2 (1776).

${ }^{39}$ Michel Troper, Sovereignty and Natural Law in the Legal Discourse of the Ancien Régime, 16 THEORETICAL INQUIRIES L. 315 (2015).

${ }^{40} \mathrm{HCJ}$ 262/62 Israel Peretz v. The Municipality of Kfar Shmaryahu, 16 PD 2101, 2115 (1962) (Isr.) (Justice Sussman).

${ }^{41}$ See, e.g., Evan Fox-DeCent, Sovereignty's Promise: The State AS Fiduciary (2012); D. Theodore Rave, Politicians as Fiduciaries, 126 HARV. L. Rev. 671 (2013). Ethan J. Leib, David L. Ponet \& Michael Serota, A Fiduciary Theory of Judging, 


\section{(b) Trusteeship beyond the state}

In an earlier article, I offered a reading of sovereignty as trusteeship for humanity. ${ }^{42}$ I argued that the way to justify the sovereign state and its endowment with exclusive jurisdiction within its boundaries is by regarding it as a trustee on behalf of all humans. This section suggests that IOs are subject to the same discipline of trusteeship that states are bound by, and that the legal discipline that trusteeship offers is a potent source of accountability duties incumbent on IOs. In that article, I submitted that the idea of sovereignty as exclusive authority (and hence trustee of its citizens only) was congruent with democratic notions as long as there was a perfect or almost-perfect fit between the sovereign and the citizens - those affected by its policies. ${ }^{43}$ Such a vision made eminent sense when sovereigns ruled discrete economies, separated from each other by rivers, deserts and other natural barriers, making cross-border externalities, such as pollution, a relatively rare event, to be resolved on the inter-sovereign level, negotiated by emissaries, ambassadors and, later, within international organizations. This solipsistic vision of sovereignty was enhanced by the notion of national self-determination that erected barriers to the demands of non-citizens to weigh in on domestic policy-making processes and shielded the domestic body politic from the obligation to internalize the rights and interests of non-citizens in their policymaking. But today, in our global condominium, the 'technology' of global governance that operates through discrete sovereign entities no longer fits. Sovereigns today cannot be likened to the owners of isolated mansions; they are more analogous to owners of small apartments in one densely packed high-rise in which about two hundred families live. This calls for a more encompassing vision of state sovereignty as embedded in a global order, which is a source not only of powers and rights, but also of obligations that essentially position states - and IOs to which states delegate authority - as trustees of all of humanity. Under this vision, they would be therefore accountable to all those affected by their policies, even if the affected were non-citizens living in faraway lands. ${ }^{44}$

There is obviously a danger associated with invoking the concept of trusteeship in the global context. Cynics will say that the notion of 'trusteeship for humanity' was invented to justify colonialism. Obviously, its underlying rationale was asserted when European powers apportioned African territory among them

101 CallF. L. ReV. 699 (2013); Ethan J. Leib \& David L. Ponet, Fiduciary Representation and Deliberative Engagement with Children, 20 J. POL. PHIL. 178 (2012); David L. Ponet \& Ethan J. Leib, Fiduciary Law's Lessons for Deliberative Democracy, 91 B.U. L. Rev. 1249 (2011). See also Evan J. Criddle, Fiduciary Administration: Rethinking Popular Representation in Agency Rulemaking, 88 TEX. L. REv. 441 (2010); Evan J. Criddle, Fiduciary Foundations of Administrative Law, 54 UCLA L. ReV. 117 (2006).

${ }^{42}$ Benvenisti, supra note 2.

${ }^{43}$ For such a functional justification of sovereignty, see also HENRY SIDGWICK, THE ELEMENTS OF POLITICS 252 (4th ed. Macmillan and Co., 1919): "the main justification for the appropriation of territory to governments is that the prevention of mutual mischief among the human beings using it cannot otherwise be adequately secured."

${ }^{44}$ Benvenisti, supra note 2; Eyal Benvenisti, Legislating For Humanity: May States Compel Foreigners to Promote Global Welfare?, in INTERNATIONAL LAW-MAKING, ESSAYS IN HONOUR OF JAN KLABBERS 3 (Rain Liivoja \& Jarna Petman eds., 2014). Compare Evan CRIDDle And Evan Fox-DeCent, Fiduciaries of HUMANITY (2016) (arguing that states are fiduciaries for their people and, collectively, for humanity at large). 
in the Scramble for Africa, ${ }^{45}$ and the League of Nations ${ }^{46}$ used trusteeship to justify a new form of colonialism. ${ }^{47}$ The problematic relationship between occupier and occupied has also been referred-to as 'grounded in trusteeship'. ${ }^{48}$ Exploitative institutions such as the Special Trustee for American Indians ${ }^{49}$ existed also under domestic law. But these examples only serve to emphasize the fundamental point that the concept of trusteeship is not based on actual trust, on confidence in the decision-maker, but to the contrary. As Niklas Luhmann suggested, the emergence of the concept of trusteeship is correlated with peoples' move from their closely-knit communities to the large cities, and their sense of lost confidence in the public actors they had known had had faith in. The concept of trusteeship was designed to offer a legal substitute for the loss of social ties. ${ }^{50}$ In other words, trust, as opposed to confidence or faith, 'involves one in a relation where the acts, character, or intentions of the other cannot be confirmed. [...] [O]ne trusts or is forced to trust - perhaps led to trust would be better - when one cannot know, when one has not the capabilities to apprehend or check on the other and so has no choice but to trust. ${ }^{51}$ Moreover, and more importantly, the version of trusteeship of humanity advocated here does not justify more powers over foreign stakeholders. In fact, it calls for just the opposite. It aims inwardly, as it requires global actors to assume burdens within their own autonomy, rather than endorsing their access to others' resources..$^{52}$

Invoking the trusteeship to humanity concept revives a venerable tradition in international law concerning the meaning of sovereignty that responds adequately to contemporary challenges. To paraphrase James Madison, IOs are, in fact, but different trustees of all human beings, because the ultimate, inherent

\footnotetext{
${ }^{45}$ General Act of the Conference of Berlin, 26 February 1885 (“. . . concern, as to the means of furthering the moral and material well-being of the native populations.")

${ }^{46}$ Antony Anghie, Colonialism and the Birth of International Institutions: Sovereignty, Economy, and the Mandate System of the League of Nations, 34 N.Y.U. J. INT'L L. \& POL. 513, 604-05 (2002) (“My argument has been that the economic and social policies actively endorsed by the PMC had profoundly damaging consequences for mandate peoples. The Mandate System, however, failed to provide any formal mechanism by which the native could communicate meaningfully with, and represent herself before, the PMC.")

${ }^{47}$ League of Nations Covenant art. 22 ("the principle that the well-being and development of such peoples form a sacred trust of civilisation and that securities for the performance of this trust should be embodied in this Covenant.").

${ }^{48}$ BENVENISTI, supra note 31, at 6; Arnold Wilson, The Laws of War in Occupied Territory, 18 TRANSACTIONS GRotIUS Soc'Y 17, 38 (1933) ("enemy territories in the occupation of the armed forces of another country constitute ... a sacred trust."); Adam Roberts, What Is Military Occupation? 55 BRITISH Y.B INT'L L. 249, 295 (1985) ("the idea of trusteeship is implicit in all occupation law."); GeRHARD VON Glahn, LAW AMONG NATIONS 686 (5th ed. 1986) (the "occupant .... exercises a temporary right of administration on a sort of trusteeship basis.").

${ }^{49}$ Cobell v. Salazar, 573 F.3d 808, 809 (D.C. Cir. 2009).

${ }^{50}$ NIKLAS LUHMANN, TRUST AND POWER (1979). See also Janne Jalava, From Norms to Trust: The Luhmannian Connections between Trust and System, 6 EUR. J. SOC. THEORY 173 (2003). According to Adam Seligman, the concept of "trust" was created in "an attempt to posit new bonds of general trust in societies where primordial attachments were no longer goods to think with." AdAM B. Seligman, The Problem of TRUST 15 (1997). I thank Neil Walker for elaborating on this point.

${ }^{51}$ SELIGMAN, supra note 50, at 21. See also Virginia Held, On the Meaning of Trust, 78 EtHICS 156, 157 (1968) ("trust is most required exactly when we least know whether a person will or will not do an action.").

52 David Luban, Nationalism, Human Rights, and the Prospects for Peace: An Essay on Sovereign Responsibilities 17 (GlobalTrust Working Paper, Paper No. 02, 2018), ("the model changes dramatically once we think of sovereigns as trustees not of a colonized people, but of humanity.").
} 
authority resides in humanity..$^{53}$ It is humanity at large that assigns certain groups of citizens the power to form national governments (and indirectly to form IOs). ${ }^{54}$ Stated otherwise, it is possible to reconceptualize Max Huber's famous vision of a global legal order that 'divides between nations the space upon which human activities are employed ${ }^{\prime 55}$ and allocates to each the responsibility toward other nations for activities transpiring in its jurisdiction that violate international law, in a relationship of trusteeship. According to Huber's viewpoint, given the precedence of human rights, sovereigns can - and should - be viewed as organs of a global system that allocates competences and responsibilities for promoting the rights of all human beings and their interest in the sustainable utilization of global resources. As trustees of this global system - to paraphrase another statement of Huber's ${ }^{56}$ - the competency of contemporary sovereigns to manage public affairs within their respective jurisdictions carries with it a corollary duty to take account of external interests and even to balance internal against external interests. The foreigner remains a foreigner, but she is not a total alien. She has a stake in any public decision, and has standing at least to demand to have her interests taken into account and also to demand an account for any policy that directly or indirectly affects her. ${ }^{57}$

Research focused on the trusteeship concept in international law at the GlobalTrust project has identified several areas in which the commitment to 'other-regardingness' or the practice of taking others' interest into account is quite prevalent among states and international tribunals, even this concept is not explicitly articulated. ${ }^{58}$ In other words, it is possible to connect all the dots where 'other-regarding' duties have been articulated to a single abstract principle that stipulates a duty of other-regardingness that is embedded in a concept of trusteeship and extended to IOs and require their accountability to those

${ }^{53}$ As Madison noted in The Federalist Papers, "[ $t$ ] he federal and State governments are in fact but different agents and trustees of the people [because] the ultimate authority . . . resides in the people alone." Madison, The Federalist, 46, in THE FEDERALIST, supra note 37, at 315, 315.

${ }^{54}$ See also Hans Kelsen, Foundations of Democracy, 66 ETHICs 1, 33-34 (1955). Kelsen prefers the

[t]heory according to which the state is not a mysterious substance different from its members, i.e., the human beings forming the state .... This doctrine .... finds this existence in the validity and efficacy of a normative order and consequently in the minds of the human beings who are the subjects of the obligations and rights stipulated by this order.... By demonstrating that absolute sovereignty is not and cannot be an essential quality of the state existing side by side with other states, it removes one of the most stubborn prejudices which prevent political and legal science from recognizing the possibility of an international legal order constituting an international community of which the state is a member, just as corporations are members of the state.

${ }^{55}$ Island of Palmas (Netherlands v. US), 2 R.I.A.A. 829, 839 (Perm. Ct. Arb.1928).

${ }^{56}$ Huber's statement in the award re. British Claims in the Spanish Zone of Morocco (Gr. Brit. v. Spain), 2 R.I.A.A. 615, 641 (Perm. Ct. Arb. 1925) ("Responsibility is the necessary corollary of rights. All international rights entail international responsibility."). See Daniel-Erasmus Khan, Max Huber as Arbitrator: The Palmas (Miangas) Case and Other Arbitrations, 18 EUR. J. INT'L L. 145, 156 (2007).

${ }^{57}$ Benvenisti, supra note 2; BENVENISTI, supra note 26, at 145-50.

${ }^{58}$ See, e.g., Eyal Benvenisti \& Sivan Shlomo Agon, The Law of Strangers: The Form and Substance of Other-Regarding International Adjudication (GlobalTrust Working Paper, Paper No. 08, 2017); Alon Jasper, Participation of Foreigners in Environmental DecisionMaking \& The Aarhus Convention (GlobalTrust Working Paper, Paper No. 06, 2017); Marka Peterson, The Federal Reserve Since the Global Financial Crisis: Do Foreign Interests Matter to the World's Economic Hegemon? (GlobalTrust Working Paper, Paper No. 03, 2016). See generally COMMUNITY INTERESTS ACROSS INTERNATIONAL LAW (Eyal Benvenisti \& Georg Nolte eds. 2018). 
affected by their acts and omissions. Such a duty could very well be included among the "obligations incumbent upon [IOs] under general rules of international law."

As trustees of humanity, then, national decision-makers - and by extension, those to whom they delegate authority, such as IOs - have an obligation to take into account the interests of all who are affected by their acts. Although sovereigns are entitled to prioritize their own citizens' needs and IOs, the citizens of their member states, they must weigh the interests of other stakeholders and consider internalizing them into their balancing calculus. This obligation to foreign stakeholders does not necessarily imply an obligation to respond to those interests, and does not even require full legal responsibility for ultimately preferring domestic interests in balancing the opposing claims. Nor does it necessarily imply that sovereign discretion should be subject to review by third parties such as foreign or international courts that would replace the sovereign's discretion with their own. What it does imply as a minimum, however, is that sovereigns consider whether the policies they adopt and pursue can be made less detrimental to foreign stakeholders or even improve their condition and otherwise promote global welfare.

This concept of trusteeship applies with even greater force to IOs whose design or intended impact is to shape the behaviour of individuals across political boundaries. ${ }^{59}$ The implication is that intergovernmental organizations, informal governance bodies coordinated by state executives and other national agencies, as global trustees, need to render account to affected foreign stakeholders and allow them voice in their decision-making processes. The question, then, is not whether administrative law norms would be suitable for IOs and other global governance bodies in their diverse areas of regulation, but rather which laws would be fit for purpose. Such rules should be tailored to the various organizations to fit their nature, their functions and their potential impact on individuals. The trusteeship concept provides the starting point for the articulation of accountability obligations.

\section{Conclusion}

"Power corrupts, and absolute power corrupts absolutely," said Lord Acton, and though in his days the phenomenon of global governance was just making its first appearances, there was no reason to expect that global governance bodies would somehow avoid the pitfalls of every human organization. As the practice over the years demonstrates, there is nothing innate in IOs, public or formally private, that defies this simple logic. The history and theory of administrative law suggest that this law's requirements are not designed against the administrative agencies, but just the opposite. The laws that structure the decisionmaking process assist the agencies, rather than burden them. The question, then, is not whether, but rather which administrative law norms would be suitable for IOs in their diverse types and areas of regulation. Such rules should be tailored to fit their nature, their functions, and their potential impact on individuals.

\footnotetext{
59 Particularly in areas under their direct administration: Hovell, supra note 31, at 7 (referring to UN territorial administration: "Where the law entrusts irresistible discretionary power over the interests of another party interests that are vulnerable by virtue of that power - this establishes a relationship premised on a presumption of trust.").
} 
The concept of trusteeship for humanity can sustain the demand for 10 accountability. The essence of this obligation is the duty to take account of all those affected by their acts and omissions and to provide account to them. Arguably, this concept is ingrained in international legal practice and is among those general rules of international law incumbent on IOs. 